\title{
尿路結石形成に関する尿中 $\alpha_{1}$ globulin 領域の蛋白の役割について
}

特に血清 $\alpha_{1}$ globulin 領域の蛋白の $\mathrm{CaCO}_{3}$ 凝集効果

東北大学医学部泌尿器科学教室 木 崎徳

\begin{abstract}
THE ROLE OF URINARY PROTEINS OF $\alpha_{1}$ GLOBULIN FRACTION IN THE FORMATION OF URINARY CALCULI

WITH SPECIAL REFERENCE TO THE AGGREGATING EFFECT OF SERUM $\alpha_{1}$ GLOBULIN ON $\mathrm{CaCO}_{8}$ SUSPENSION
\end{abstract}

\author{
Noboru Kisaki \\ Department of Urology, Thohku University School of Medicine, Sendai
}

It is well known that not only patients with renal disease but healthy individuals also excrete proteins in the urine. However, the role played by urinary protein in the formation of stones is not as yet clearly understood. The present study was undertaken to determine if urinary protein has an action to form a stone and if so what types of protein possess such an action.

Materials and Methods: Normal human serum was separated into fractions by the use of ammonium sulfate and further refractionated with DEAE cellulose. Each of the fractions thus obtained was tested for its stone-forming action by measuring the increase in the sedimentation rate of a suspension of $\mathrm{CaCO}_{3}$ fine particle and the change in $\zeta$-potential of this suspension that occurred on addition of these fractions. Also, proteins separated by electrophoresis through a cellulose acetate film were identified.

Results: Proteins of $\gamma$ - and $\beta$-globulin fractions were found to exert little aggregating action on $\mathrm{CaCO}_{3}$ suspension. Most marked aggregation and precipitation of the colloidal substance were observed with proteins of $\alpha_{1}$-globulin fraction or with a mixture of $\alpha_{1}$-globulin and albumin.

From these findings it was considered that proteins of $\alpha_{1}$-globulin fraction or a mixture of proteins of $\alpha_{1}$-globulin and albumin in urine are the most likely predominant factor in the formation of stones in urine.

\section{緒言}

我々は前報1 で炭酸カルシウム微細粒子の suspension 溶液の sedimentation rate および zeta-potential を測 定することにより，尿路結石の発生に関する matrix substance の役割について報告した。すなわち, matrix subrtance が尿中 colloid 粒子の zeta-potential を減少 させることにより, collid の凝集が起り，これが沈涮し たのち, 適当な運動エネルギーが与兄られると凝塊が形 成されてくる．これが核となつて結石が形成されるので はないかと報告した。

このように凝集作用をもち, matrix substance となり 得る尿中排泄物のうち, これまで酸性ムコ多糖類が主に 注目されて来たが, 我々は凝集作用のある尿中排泄物は
}

これだけではなく, albumin などの蛋白も凝集作用をむ つていることを前報で報告した。

一方, 腎病変時のみならず, 健康者に执いても, 血清 中に存在しているときとは変つた形であつても血清由来 の蛋白が尿中に排泄されるが，この尿中蛋白が尿路結石 の発生にどのような役割をもつか不明である.

そこで今回, ヒト血清を分画し, 各画分に甜ける尿中 colloid の凝集, 沈降能力を炭酸カルシウム suspension 溶液の zeta-potential 拉よび sedimentation rate で測定 し，結石形成に強く作用している蛋白を検索した。

\section{実験材料および方法}

\section{1. 実験材料}

硫安分画, DEAE cellulose 分画のため 正常ヒト血清 
280ml を使用した（血清 A). 別に, 高濃度の硫安で蛋 白を分画するため, さらに正常ヒト血清 $280 \mathrm{ml}$ を使用 した（血清 B).

2. 血清蛋白の硫安分画

上記のヒト血清 $280 \mathrm{ml}$ (血清 A) 飞硫安を順次, 最終 濃度が10\%，20\%，30\%となるように加光た。硫安は常 温にて少量ずつ加えて沈澱を起こした。硫安の各濃度に 扣ける沈澱をそれぞれ遠心分離（10.000rpm，15分間）

した。各々の沈澱と $30 \%$ 硫安を加えた後の上清を蒸水に て透析した. 透析は $4{ }^{\circ} \mathrm{C} に て$ 行ない, 蒸溜水は 1 日 1 回 交換し，3 日間行なつた。なお，上清の透析は 6 日間行 ない，充分に透析した。透析後 $35 \sim 40^{\circ} \mathrm{C}$ に回転濃縮 し，凍結乾燥を行なつた。

別の $280 \mathrm{ml}$ の血清（血清 B ）に対しては34\%になる ように硫安を加えて沈澱させ，この沈澱を除去（10.000 $\mathrm{rpm}, 15$ 分間遠心分離）した上清に 最終濃度 が50\%およ び68\%となるように硫安を加光，50\%および68\%飽和の 沈澱を得, この沈澱を上記と同様の方法で透析, 濃縮,

凍結乾燥を行なつた。

3. DEAE-Cellulose columm による分画

硫安分画によつて得られた粗画分の蛋白を内径 2.2 $\mathrm{cm}$, 高さ $25 \mathrm{~cm}$, 容積 $95 \mathrm{~cm}^{3}$ の DEAE-Cellulose column に通し, $0.01 \mathrm{M}$ phosphate buffer $(\mathrm{pH} 6.8), 0.05 \mathrm{M}$ phosphate buffer ( $\mathrm{pH} 6.8$ ), 0.1 M phosphate buffer (pH 6.8)および0.1 M phosphate buffer+0.1 M Nacl 溶 液（等量混和 $\mathrm{pH}$ 6.8）を各 $500 \mathrm{ml}$ ずつ流し, 順次溶出 し, 順次溶出した（表 1).

溶液中の蛋白量は spectrophotometer（日立製作所製， Model 110）を用いて自動記録装置に接続し，280nm で 吸収測定した．得られた蛋白を各 peak ごとに集め， 3 日間蒸溜水にて透析したのち，35〜 $40^{\circ} \mathrm{C} て ゙$ 回転濃縮し, 凍結乾燥を行なつた。

4. 蛋白の電気泳動

上記の方法で得られた蛋白画分 $0.5 \mathrm{mg}$ を $0.2 \mathrm{ml}$ の生 理的食塩水に溶解し $(0.25 \%)$, veronal buffer $(\mathrm{pH} 6.8)$ に浸した Cellulose acetate 膜上に10 $\mu \mathrm{g}$ ずつ apply し た。

電気泳動の条件は cellulose acetate 膜の幅 $1 \mathrm{~cm}$ に つき $1 \mathrm{~mA}$ を流し $(220 \mathrm{~V}), 40$ 分間電気泳動した。電気 泳動終了後は cellulose acetate 膜上の蛋白を Amido Black 10B および PAS にて染色した. 尚, cellulose acetate 膜は常光産業製 Separax を使用した.

5. 炭酸カルシウム suspension 溶液の作成法
表 1 DEAE Cellulose Columnによる分画（画分 4 150mg を分画)

DEAE Cellulose Column

(内径 $2.2 \mathrm{~cm}$, 高さ $25 \mathrm{~cm}$, 容皘 $95 \mathrm{~cm}^{3}$ )

$0.01 \mathrm{M}$ phosphate bufferで溶出.........P1

$\downarrow \quad(\mathrm{pH} 6.8)$

$0.05 \mathrm{M}$ phosphate buffer で溶出……..P2

$\downarrow \quad(\mathrm{pH} \quad 6.8)$

$0.1 \mathrm{M}$ phosphate buffer で溶出……... 33

$\downarrow \quad(\mathrm{pH}$ 6.8)

$0.1 \mathrm{M}$ phosphate buffer ( $\mathrm{pH} 6.8$ )

$+0.1 \mathrm{M} \mathrm{Nacl}$ で溶出 ……........... P4

表 2 硫安分画に上る血清蛋白の分画（血清 $280 \mathrm{ml}$ )

\begin{tabular}{|c|c|c|c|}
\hline 画 & 分 & & 量（g） \\
\hline \multirow{4}{*}{$\begin{array}{l}\text { 血清 } \\
(\mathrm{A})\end{array}$} & 1 & & 1.01 \\
\hline & 2 & & 5.62 \\
\hline & 3 & & 10.49 \\
\hline & 4 & & 0.36 \\
\hline \multirow{2}{*}{$\begin{array}{l}\text { 血清 } \\
\text { (B) }\end{array}$} & 5 & & 0.21 \\
\hline & 6 & & 0.18 \\
\hline 血清（A） & $\begin{array}{l}\text { 画分 } 1 \\
\text { 画分 } 2 \\
\text { 画分 } 3 \\
\text { 画分 } 4\end{array}$ & \multicolumn{2}{|c|}{ 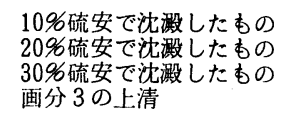 } \\
\hline 血清 (B) & $\begin{array}{l}\text { 画分 } 5^{*} \\
\text { 画分 } 6^{*}\end{array}$ & \multicolumn{2}{|c|}{$\begin{array}{l}50 \% \text { 飽和で沈港したもの } \\
68 \% \text { 飽和で沈湟したあの }\end{array}$} \\
\hline
\end{tabular}

* 34\%硫安で上清にきた画分について実施

表 3 DEAE-Cellulose Column に上る分画（画分 4， 150mg を分画)

\begin{tabular}{c|c}
\hline 分 画 & 収 \\
\hline P 1 & 3.6 \\
\hline P 2 & 10.0 \\
\hline P 3 & 67.4 \\
\hline P 4 & 9.2 \\
\hline 合 計 & 90.2 \\
\hline
\end{tabular}

炭酸カルシウム粒子の zeta-potential および sedimentation rate の測定法.

直径約 $8 \mu$ にした炭酸カルシウム微細粉末の suspension を使用し, 前報 ${ }^{1)}$ と同様の方法で，この suspension の sedimentation rate および suspension 粒子の zetapotential を測定した。これらの方法により炭酸カルシ ウム suspension 粒子に対する上記の分画した蛋白の凝 
集効果を測定した。

分画した蛋白を加えたときの $\mathrm{CaCO}_{3}$ suspension の $\mathrm{pH}$ は Lab-O-meter (Beckman-Toshiba 製) にて測定 した。

\section{実験成繢}

\section{1. 硫安分画による収量}

血清 A に10\%，20\%㧊よび30\%になるように硫安を加 えた際の沈澱抢よび30\%になるように硫安を加えた上清 より得られた蛋白画分をそれぞれ画分 1 , 画分 2 , 画分 3 および画分 4 とした。 また血清 B $550 \%$ および $68 \%$ 硫 安飽和により得られた蛋白をそれぞれ画分 5 および画分 6 とした。

各画分の収量は表 2 の通りである。すなわち，画分 $1,1.01 \mathrm{~g}$; 画分 $2,5.62 \mathrm{~g}$; 画分 $3,10.49 \mathrm{~g}$; 画分 4 , $0.36 \mathrm{~g}$; 画分 $5,0.21 \mathrm{~g}$; 画分 $6,0.18 \mathrm{~g}$ であつた.

2. $\mathrm{CaCO}_{3}$ suspension の zeta-potential および sedimentation rate に対する硫安による粗画分蛋白の 影響.

各画分の蛋白を $\mathrm{CaCO}_{3}$ suspension に最終濃度が $10^{-1}$ 〜 10-5\%となるように加光，この suspension 粒子の sedimentation rate と zeta-potential の変化を測定した.

画分 1 ，画分 2 拈よび画分 6 では $5 \times 10^{-3} \%$ 打よび $10^{-2} \%$ と比較的高濃度に加えたときのみ沈降速度の亢進 が認められた（図 1，2，3）. 画分 3 では $10^{-3}$ および $5 \times 10^{-3} \%$ で $\mathrm{CaCO}_{3}$ 粒子の沈降促進が認められたが, $10^{-3} \%$ 濃度では沈降速度がかなり遅れるのが認めら れた（図 4)。これに対し，画分 4 は $10^{-3} \%$ および $5 \times$ $10^{-3} \%$ で，また，画分 5 は $5 \times 10^{-3} \%$ および $10^{-3} \%$ で著明 な沈降速度の充進が認められた（図 5，6）。

つぎに $\mathrm{CaCO}_{3}$ 粒子の zeta-potential の変動について みると画分 1 および画分 2 ではこれらの画分の濃度が 5 $\times 10^{-3} \%$ 附近より減少がはじまり，どちらも $10^{-2} \%$ 附近 で電位は 0 となり,これより高濃度では電位の逆転が認

図 $1 \mathrm{CaCO}_{3}$ Suspension 溶液の沈降速度に対する 画分 1 の効果

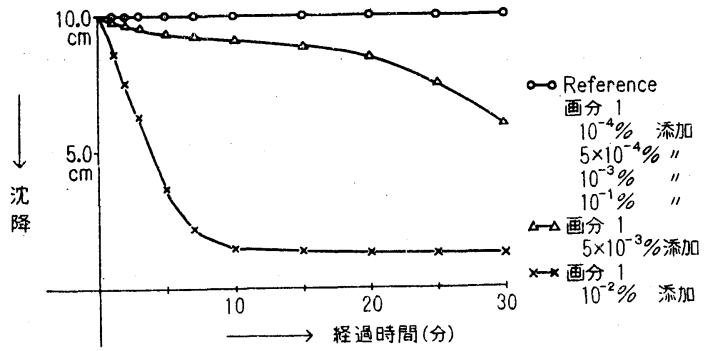

図 $2 \mathrm{CaCO}_{3}$ Suspension 溶液の沈降速度に対する 画分 2 の効果

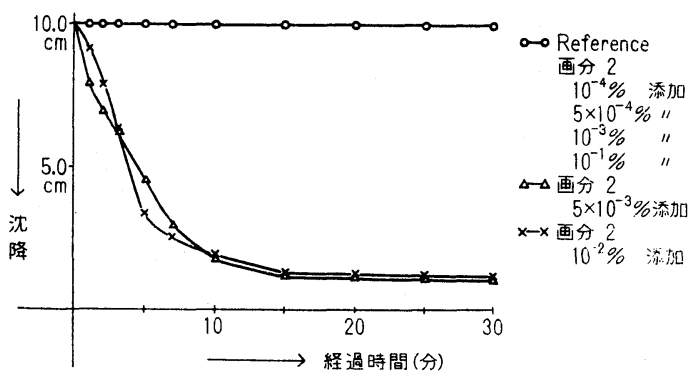

図 $3 \mathrm{CaCO}_{3}$ Suspension 溶液の沈降速度に対する 画分 6 の効果

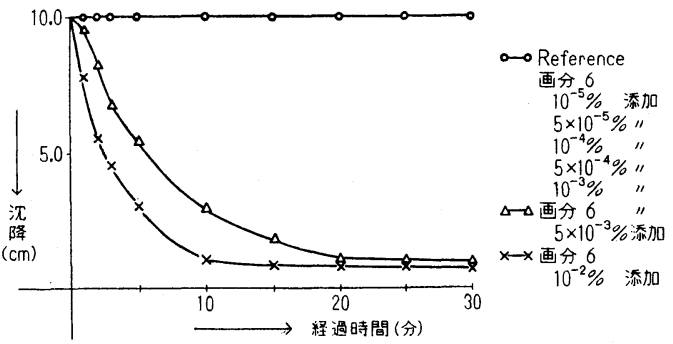

図 $4 \mathrm{CaCO}_{3}$ Suspension 溶液の沈降速度に対する 画分 3 の効果

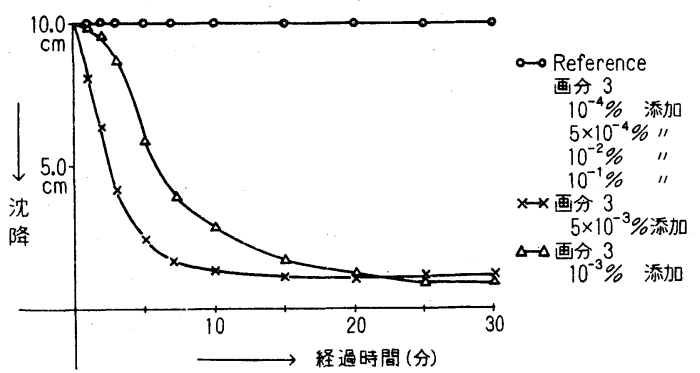

因 $5 \mathrm{CaCO}_{3}$ Suspension 溶液の沈降速度に対する 画分 4 の效果

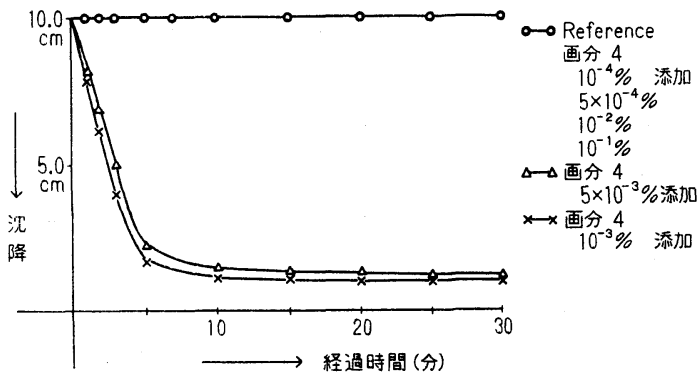


図 $6 \mathrm{CaCO}_{3}$ Suspension 溶液の沈降速度に対する 画分 5 の効果

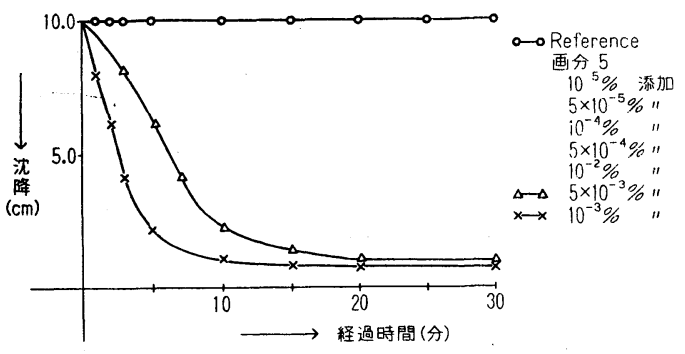

圀 $7 \quad \mathrm{CaCO}_{3}$ Suspension 溶液中の $\zeta$-Potential に 対する血清蛋白画分の効果

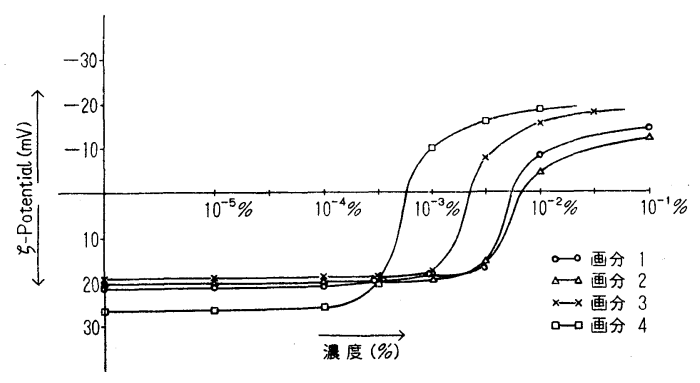

図 $8 \mathrm{CaCO}_{3}$ Suspension 溶液中の $\zeta$-Potential に 対する血清蛋白画分の効果

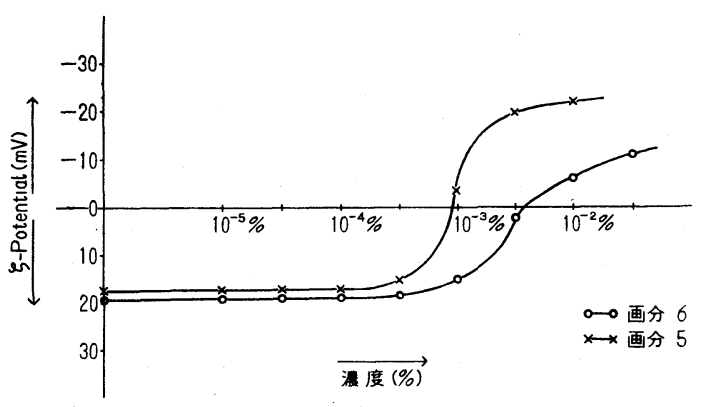

められた（図 7). 画分 3 および画分 6 では $10^{-3} \%$ 附近 より zeta-potential の減少が起り, $5 \times 10^{-3} \%$ 附近で電 位が 0 となり, それ以上の高濃度では電位が逆転した (図 7，8). また画分 5 は $5 \times 10^{-4} \%$ よ電位の低下 が起り，10-3\%附近で 0 となりこれより高濃度になると 電位の逆転がみられた（図 8). 一方, 画分 4 は, $10^{-4}$ \%附近より電位の低下しはじめるのが認められ，5× $10^{-4} \%$ と $10^{-3} \%$ の間の濃度で電位が 0 となり，これより 高濃度になると電位の逆転が認められた（図 7).すなわ ち, zeta-potential の変化よりみると, 画分 4 の $\mathrm{CaCO}_{3}$ suspension に対する凝集作用は画分 $1 \sim 6$ の中で最も強
いことが判明した. 画分 4 は, 画分 5 と画分 6 およびそ の上清に含まれる成分の混合物とみなされるので，68\% 硫安上清に含まれる成分もかなり重要な役割を演じてい るものと考えられる。

3. DEAE-cellulose column による分画

硫安分画により得られた血清蛋白の粗画分のうち, 画 分 4 が $\mathrm{CaCO}_{3}$ suspension 粒子に対して最も強い凝集 能力をもつことが判明したので，この画分150mg を DEAE-Cellulose column にて再分画した.

画分 4 を DEAE-Cellulose column に通し，0.01M， $0.05 \mathrm{M}, 0.1 \mathrm{M}$ phosphate buffer および0.1M phosphate buffer に0.1M Nacl 溶液を等量加えた溶液で順次溶出 すると, 図9のような 4 つの明瞭な peak が得られた. これらの peak を出現の順に $\mathrm{P}_{1}, \mathrm{P}_{2}, \mathrm{P}_{3}$, および $\mathrm{P}_{4}$ と すると, これらの peak を含む各 fraction より得られ た蛋白の収量は表 3 の通りである.すなわち， $\mathrm{P}_{1}, 3.6$ $\mathrm{mg} ; \mathrm{P}_{2}, 10.0 \mathrm{mg} ; \mathrm{P}_{3}, 67.4 \mathrm{mg} ; \mathrm{P}_{4}, 9.2 \mathrm{mg}$ で総計 $90.2 \mathrm{mg}$ であり, この収量は Column を通す前の150mg に対し，60.1\%であつた。 また各 fraction の割合は， $\mathbf{P}_{1}, 3.9 \% ; \mathbf{P}_{2}, 11.1 \% ; \mathbf{P}_{3}, 74.7 \% ; \mathbf{P}_{4}, 10.2 \%$ と $\mathbf{P}_{3}$

図 9 DEAE-Cellulose による分画（硫安画分 4, $150 \mathrm{mg}$ を溶出)

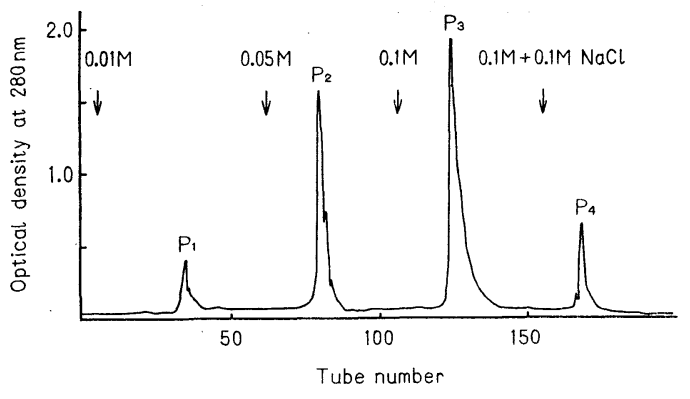

図10 $\mathrm{CaCO}_{3}$ Suspension 溶液の沈降速度に対する P 1 の効果

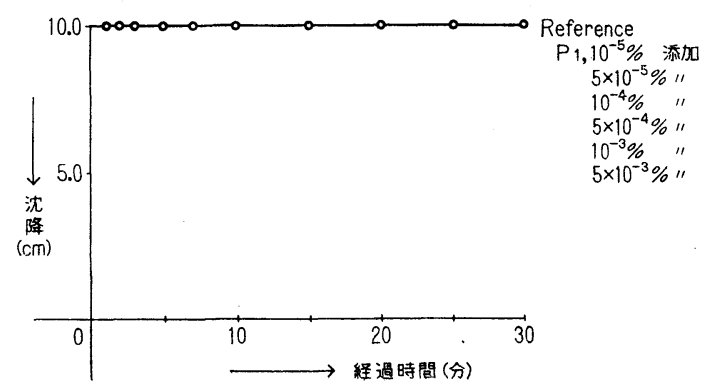


が最も多かつた。

4. DEAE-Celluloumn による分画より得られた蛋 白の $\mathrm{CaCO}_{3}$ suspension の sedimentation rate 拉よび zeta-potential に対する影響。

まず得られた各画分の sedimentation rate に対する影 響についてみると， $\mathrm{P}_{1}$ *では $\mathrm{CaCO}_{3}$ suspension はどの 濃度に执いても全く沈降しなかつた（図10）， $\mathbf{P}_{2}$ では， $\mathrm{CaCO}_{3}$ suspension の沈降は $10^{-2} \%$ と比較的高濃度に打い てのみ認められ（図11）， $\mathrm{P}_{4}$ では $10^{-3} \%$ 打よび10-2\%に て suspension の沈降が認められた（図12）。これらに対 し， $\mathrm{P}_{3}$ は $5 \times 10^{-4} \%$ 抢よび $10^{-3} \%$ の濃度で著明に沈降す

図11 $\mathrm{CaCO}_{3}$ Suspension 溶液の沈降速度に対す P 2 の効果

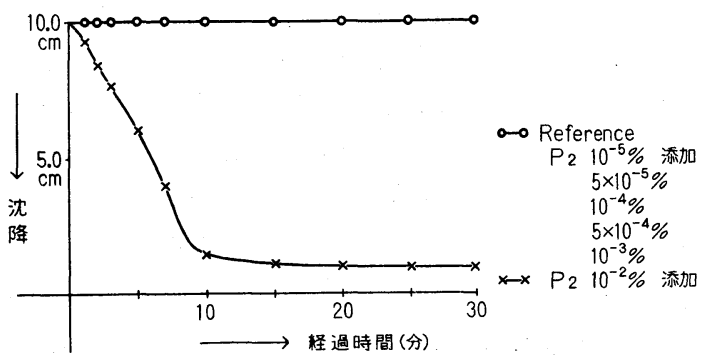

図12 $\mathrm{CaCO}_{3}$ Suspension 溶液の沈降速度に対する P 4 の効果

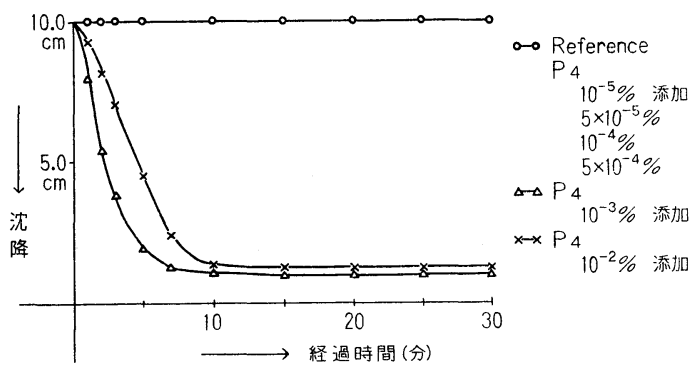

図13 $\mathrm{CaCO}_{3}$ Suspension 溶液の沈降速度に対する P 3 の効果

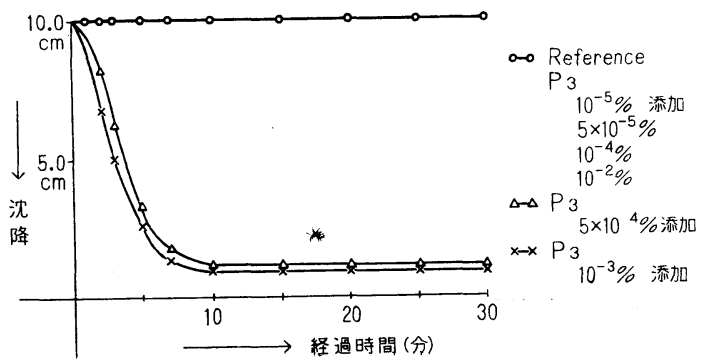

図14 $\mathrm{CaCO}_{3}$ Suspension 溶液中の $\zeta$-Potential $に$ 対する DEAE-Cellulose 分画で得られた各画分の 影響

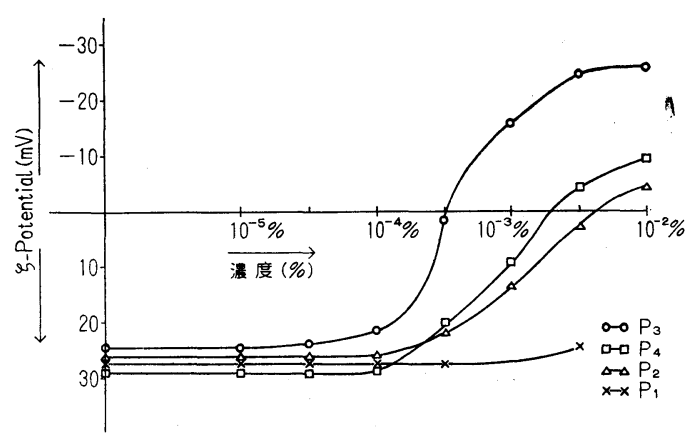

るのが認められた（図13）.

*脚注 : $\mathrm{P}_{1}$ の収量が少ないため， $10^{-2} \%$ の濃度のもの は作れず， $5 \times 10^{-3} \%$ 10-5\%の間の濃度に拈いて sedimentation sate 括よび zeta-potential の変化を測定し た.

つぎに，これらの各画分の蛋白を加えたときの zetapotential の変動についてみると, $P_{1}$ では zeta-potential は10 $0^{-5} \sim 5 \times 10^{-3} \%$ の間で殆んど変化しなかつた（図14）. $\mathrm{P}_{2}$ では $5 \times 10^{-4} \%$ の濃度で zeta-potential の減少しは じめるのを認め, さらに高濃度にすると電位が減少 し， $5 \times 10^{-3}$ 附近で 0 となるのが認められた。これよ り高濃度では電位は逆転した。 $\mathrm{P}_{3}$ では $10^{-4} \%$ 附近より

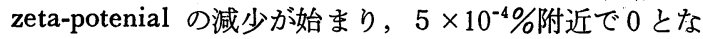
り,さらに高濃度になると電位の逆転を認めた。 $\mathrm{P}_{4}$ を添 加した場合には $5 \times 10^{-4} \%$ 附近より zeta-potential が減 少し始め, $10^{-3} \%$ 附近で電位が 0 となり，それより高濃 度になると電位が逆転するのが認められた。

以上の成績より各画分の $\mathrm{CaCO}_{3}$ の suspension に対す る凝集効果を sedimentation rate および zeta-potential の 0 となる濃度を指標として比較すると, $P_{3}$ が最も強 く， $\mathrm{P}_{4}$ がこれに次いだ． $\mathrm{P}_{2}$ は凝集作用が弱く， $\mathrm{P}_{1}$ は 殆んど凝集作用をもたないと考えられた。

5. DEAE-Cellulose Column による分画より得られ た蛋白の電気泳動.

41歳健康男子の血清を対照とし, Cellulose acetate 膜 による電気泳動を行なつた。

$\mathrm{P}_{1}$ は $\gamma$-globulin 領域の蛋白のみ認められ, $\mathrm{P}_{2}$ は $\beta$ globulin 領域の蛋白が主成分をなし，これに $\alpha_{1}$-globulin, albumin および prealbumin が極く軽度に存在するのが 認められた（図15). $P_{4}$ は albumin が主成分であり，こ 
図15 DEAE-Cellulose 分画の電気泳動

\section{Reference}

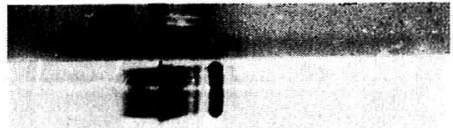

$P_{1}$

$P_{2}$

\section{Reference}

$P_{3}$

$\mathrm{P}_{4}$

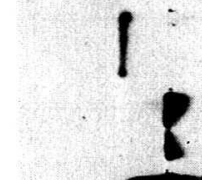

:

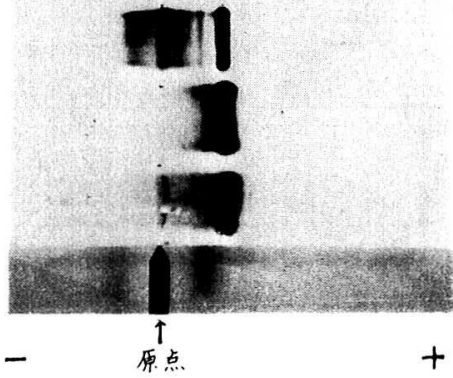

Cellulose Acetate 膜による電気泳動。各分画を0.25 $\%$ の溶液にし, $10 \mu 1$ ずっ apply. Cellulose Acetate 膜 $1 \mathrm{~mA} / \mathrm{cm}$ で40分間電気泳動した後, Amido Black 10 Bにて染色した。

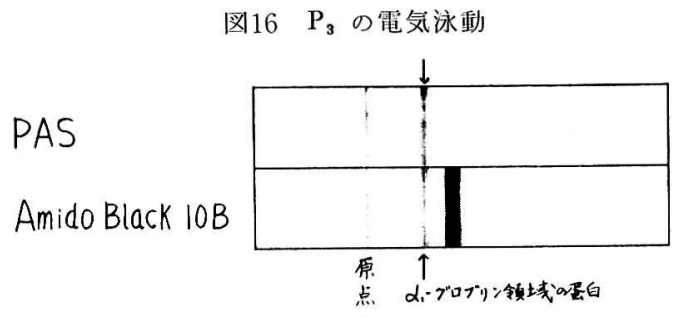

Cellulose Acetate 膜による電気泳動

図15と同じ条件で電気泳動後, PAS おょび Amido Black 10 B にて染色. Amido Black 10Bにて染色さ れている知印の部分に一致してPAS にても染色さ れている。

れに $\alpha_{1}$-globulin に一致する薄い Band が認められた。 一方, 最も強力な凝集作用を示した $\mathrm{P}_{3}$ には albumin の 濃厚な Band の他に $\alpha_{1}$-globulin に一致するかなり濃厚 な Band が浔められた。

さらに $\mathrm{P}_{3}$ についてのみ同様な電気泳動を行ない, Amido Black 10B 打よび PAS で染色を行ならと $\alpha_{1}$ globulin 領域の䖝白の部分に一致して PAS 染色陽性の Band が認められた（図16）.

6. 血清蛋白各画分を加えたときの $\mathrm{CaCO}_{3}$ suspension 溶液の $\mathrm{pH}$.

今回の実験で得られた血白の 各画分を顺たときの
$\mathrm{CaCO}_{3}$ suspension の $\mathrm{pH}$ の変動はすべて7.8〜8.5の 閒にあつた。この変動の範国は $\mathrm{CaCO}_{3}$ suspension の sedimentation rate 拈よび zeta-potential に殆んど影響 を与えないことが判明しているので，各画分を加えた 際の $\mathrm{pH}$ の変動による sedimentation rate 拈よび zetapotential への影響は殆んどなかつたと考えられる.

\section{考按}

腎病桨時のみならず正常者の尿中にも蛋白の排泄され ていることは広く涊められている。この蛋白量は報告者 により多少異なるが，1日数10mg から数100mg である とされている(2)37456778). 先疫電気泳動法により, これ らの兊白の種類を検討すると， $\alpha_{2}$ および $\beta$ lipo-protein などの巨大な蛋白を除いて殆んどすべての血清蛋白が， 血清の中に存在する形のままとは言えないまでも尿中に

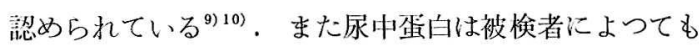
異なるが，血清蛋白の数千〜数万分の 1 程度である ${ }^{11)}$. そして血清に比べ, albumin が相対的に少なく, globulin が多いこと，特に $\alpha_{1}$ および $\alpha_{2}$ globulin が多いとされ ている310).

つぎに病的状態，とくに糸球体腎炎，腎亚腎炎おょび 尿路結石症に拈ける尿中蛋白の排泄についてみると，一 般に糸球体腎炎では尿中に albumin の排泄が多く, globulin は少ないと報告され，腎需炎では albumin の 排泄量はやはり多いが, globulin の尿中排泄量が多くな り, albumin と同程度の排泄量が認められている ${ }^{12)}$ ここ の際の globulin の増加は $\alpha, \beta, \gamma$ 各領域の globulin の増加が認められるが，特に $\beta$ および $\gamma$ globulin の増 加が著しいとされている.

一方, Boyce ${ }^{13)}$ は非感染性の尿路結石症の患者におけ る24時間尿中の蛋白の 総排泄量は正常者に比較してあ まり增加していないが，その性状にはかなり相違のある ことを指摘している。彼は分子量20.000以上の veronal buffer に可溶性の尿中蛋白を RS-1 Fraction 之名つけて 分類しているが，この中には albumin， $\alpha_{1}, \alpha_{2}$ globulin, $\beta$ globulin および $\gamma$ globulin が含まれる.このらち $\alpha_{1}$ globulin は正常者では RS-l Fraction $04.6 \%$ に過ぎ ず，また腎侖腎炎でも2.8\%なのに対し，尿路結石症で は28.4\%と多量に排泄されていることる報告している。 またこのような相対的増加のみならず，腎需腎炎の患 者, あるいは正常者に較らべ尿中 $\alpha_{1}$ globulin の絶対量 も增加していることを示している。

今回, このような $\alpha_{1}$ globulin が尿路結石の発生にな んらかの役割をもつかどらかを検討する目的で本実験を 
行なつたものである.

正常ヒト血清を用いてまず硫安分画を行なつた。最終 濃度が10\%，20\%捄よび30\%になるように硫安を加え， 血清蛋白の粗分画を行ない，さらに別の血清にて50\%飽 和抒よび $68 \%$ 飽和の硫安分画を行なつた。この方法では 分子量の大きい蛋白より順次沈澱することが認められて いる。硫安を10\%，20\%，30\%となるよらに加えたとき の沈澱および30\%硫安加の上清より得られた蛋白を，そ れぞれ画分 1 , 画分 2 , 画分 3 抢よび画分 4 とし, さら に別の血清の50\%硫安飽和による画分と画分 $5 ， 68 \%$ 飽 和による画分を画分 6 とした。そしてこれらの粗画分の 蛋白が，尿中コロイドに対してどのよらな凝集，沈降作 用をもつか $\mathrm{CaCO}_{3}$ suspension 溶液にこ北らの画分を 加穴たときり suspension 粒子の zeta-potential および sedimentation rate の変化を測定することにより検討し た。な扔，zeta-potential および sedimentation rate の 測定法は既報1)にて報告した。

今回の実験においてては, 炭酸カルシウム snspension 溶 液を凝集効果の測定法の材料として選んだが，これは炭 酸カルシウムの結石が稀であつても無いわけではない こと, さらに苳酸カルシウム, 燐酸カルシウムの suspension に較べ非常に安定して和り, 凝集打よび沈降実験 において再現性の高い成績が得られるためである。

まず $\mathrm{CaCO}_{3}$ suspension に各画分を加えた際の sedimentation rate の克進についてみると, 画分 4 と画分 5 が最も稀薄な濃度で sedimentation rate を元進させるの が認められた。つぎに薄い濃度より次第に高濃度に各画 分を加えた際の zeta-potential の変化についてみると, 画分 4 が最も低い濃度で電位の減少がはじまり, また最 も低い濃度で電位が 0 となつた。 zeta-potential が減少 し，0となることは suspension 粒子の凝集の起こること を意味し，また電位が逆転して大きくなると，逆に粒子 の分散が起こつてくる.このため濃度が大きくなるに従 いsuspension 粒子の沈降速度が方進するが, 至適の条件 からずれるにつれ, 稀い濃度では $\mathrm{CaCO}_{3}$ の粒子が陽に 荷電, 一方濃い場合には負に荷電し，いずれも分散する ことになる。

そこで各画分り $\mathrm{CaCO}_{3}$ suspension 亿刘与す凝集能） を zeta-potential が 0 となる濃度で比較すると, 画分 4 は画分 5 に対し2.5倍, 画分 3 亿対し 5 倍，画分 6 亿対 し10倍，画分 1 および画分 2 な対しては50倍の凝集作用 のあることが認められた。

そこで，この画分 4 をDEAE-Cellulose column にて
再分画し，画分 4 の中に含ま机るどの領域の蛋白がこ のような凝集作用をもつか検討した．DEAE-Cellulose column で画分 4 を溶出すると図 9 のように 4 つの画分 に明瞭に分けることができたが，それらを溶出された順 に $\mathrm{P}_{1}, \mathrm{P}_{2}, \mathrm{P}_{3}, \mathrm{P}_{4}$ と名づけるとその収量は表 3 の通り で $P_{3}$ が最も多く得られた。

DEAE-Cellulose Columm で分離した各画分の $\mathrm{CaCO}_{3}$ suspension 溶液の sedimentation rate に対する影響に ついてみると， $\mathrm{P}_{1}$ および $\mathrm{P}_{2}$ を加えても sedimentation rate の六進は汪とんぞ認められなかつた。 $\mathrm{P}_{4}$ では10 \%の濃度で sedimentation rate の充進がみられたが， $\mathrm{P}_{3}$ は $5 \times 10^{-4} \%$ と最も薄い濃度で sedimentation rate の光 進するのが認められた。

また zeta-potential の変化についてみると， $\mathrm{P}_{1}$ の添 加によつては殆んど電位の変化がみられず，また $\mathrm{P}_{2}$ で は $5 \times 10^{-3} \%$ とかなり高濃度の添加で電位の低下が始ま り，また $10^{-2} \%$ で電位が 0 となることが認められた。ま た $\mathrm{P}_{4}$ では zeta-potential は5 $5 \times 10^{-4} \%$ より低下しはじ め, $10^{-3} \%$ 附近で 0 となつた。これに対し， $\mathrm{P}_{3}$ では $5 \times$ $10^{-5} \%$ と他の画分に比べ最も低い濃度で zeta-potential が減少しはじめ， $5 \times 10^{-4} \%$ と最も低い濃度で 0 となる ことが認められた。すなわち, zeta-potential が 0 とな る濃度で比較すると $\mathrm{P}_{3}$ は $\mathrm{P}_{4}$ の約7.5倍, $\mathrm{P}_{2}$ の約50倍 の凝集効果のあること，そして $\mathrm{P}_{1}$ は凝集作用を全く持 たないことが判明した。

そこでこれら画分がいかなるものか Cellulose acetate 膜にて電気泳動を行ない検討したい。

$\mathrm{P}_{1}$ は $\gamma$ globulin 領域の蛋白のみが認められ， $\mathrm{P}_{2}$ は $\beta$ globulin 領域の蛋白が主体であり, これらの蛋白は $\mathrm{CaCO}_{3}$ suspension に対する凝集作用は殆んどなく, 結 石形成には殆んど関与していないと考兄られた。

$\mathrm{P}_{3}$ および $\mathrm{P}_{4}$ には明瞭な albumin 領域の蛋白の存在 がみられ，さらに $\mathrm{P}_{3}$ には著明な $\alpha_{1}$ globulin 領域の蛋 白の存在が認められた，さらにこの Band をPAS 染色 すると陽性に染色され糖蛋白の存在が認められた。

我々は前報》で bovine albumin が $\mathrm{CaCO}_{3}$ suspension に対して凝集作用をもつことを報告したが，この成績よ

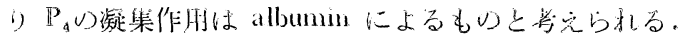
これに対して $\mathrm{P}_{3}$ は最も強力な凝集効果を示したが，こ 机は albumin に加兄て $\alpha_{1}$ globulin 領域の蛋白の存在 に上ると考兄られる。その理由は下記の如くである。す なわち，albumin は直鎖性の高分子なので suspension 粒子に対して凝集作用をもつことが考完られ，また $\mathrm{P}_{3}$ 
の電気泳動で $\alpha_{1}$ globulin に一致する Band が PAS 陽 性であり, シアロ糖蛋白を含んでいる可能性が強く, 球 状の分子構造をもつていてもシアル酸の存在に基づく負 の荷電によつて凝集効果を示すと考えられる.さらに68 \%硫安飽和の画分, すなわち画分 6 は albumin が主体 であるが，この凝集作用は $\mathrm{P}_{4}$ とほぼ一致し，あまり強 カでないこと, 特よび albumin と globulin の存在する 硫安画分 4 が強力な凝集作用を示すことによる.ただ現 在までのところ $\alpha_{1}$ globulin 領域の蛋白が単独でこのよ うな作用をもつか, albumin との共存が必要なのか明確 ではない。これに関しては今後検討を続ける予定であ る.

このような in vitro の成績を臨床面から考察すると， 前述したように尿路結石患者の尿中には，Boyce ${ }^{13)}$ によ ると， $\alpha_{1}$ globulin が平均 $58 \mathrm{mg} / \mathrm{day}$, albumin が平均 59 $\mathrm{mg} /$ day とかなり多量の $\alpha_{1}$ globulin と albumin が排泄 されて括り, この際の尿量を $2.000 \mathrm{ml}$ とすると, この両 蛋白を加光た尿中濃度は $5 \times 10^{-5} \%$ となり，これだけで も $\mathrm{P}_{3}$ の zeta-potential を減少させはじめる濃度に汇ぼ 近くなる. 尿中蛋白の排泄量にも日間変動が認められて 物 ${ }^{8)}{ }^{10)} ， \alpha_{1}$ globulin あるいは $\alpha_{1}$ globulin+albumin 領域の蛋白は尿中コロイドの凝集, 沈降を起こす濃度に 充分達し得ると考兄られる.しかしながら尿中に排泄さ れた蛋白は血清中の蛋白そのものとは考兄られず, 血清 蛋白の凝集能力がそのまま尿中の蛋白にあてはまるとは 考えられないが, これらの蛋白は結石形成の重要な因子 の1つであると言えよう.

一方, 前述したように糸球体腎炎, 腎㙉腎炎では蛋白 尿が出るが，この中には $\alpha_{1}$ globulin は少ないことが認 められて拉り, 今回の成績は $\alpha_{1}$ globulinを欠いた場合 には蛋白尿が出ても必ずしも結石形成に結びつかないこ とを示している。

\section{結 語}

尿路結石症患者においては正常者あるいは他の蛋白尿 の出る疾患に比べ，尿中 $\alpha_{1}$ globulin 排泄量の多いこと が報告されているが，その生理的意義は不明である。

そこで今回 $\alpha_{1}$ globulin が尿路結石の発生にいかなる 役割をもつかを炭酸カルシウム suspension 粒子に対す る凝集効果にて検討した。

\section{実験材料および方法}

正常ヒト血清 $280 \mathrm{ml}$ を最終濃度がそれぞれ $10 \% ， 20$ $\%, 30 \%$ 硫安で分画し, 別の 血清 $280 \mathrm{ml}$ を $50 \%$ 硫安飽 和, $68 \%$ 硫安飽和で分画した。ささら DEAE-Cellulose
Columm で再分画した。得られた各画分の 結石形成作 用を，これらの画分を加えた際の $\mathrm{CaCO}_{3}$ 微細粒子 suspension に対する sedimentation rate の充進括よび zeta-potential の変化により測定した。をた Cellulose acetate 膜による電気泳動法により得られた蛋白画分の 種類を同定した。

成績

1）硫安分画に上る蛋白

$10 \% ， 20 \% ， 30 \%$ 硫安加の沈澱より得た画分をそれぞ れ画分 1 , 画分 2 , 画分 3 とし, $30 \%$ 硫安加の上清より 得られた蛋白を画分 4 とした。 また $50 \%$ 硫安飽和より得 られた蛋白を画分 $5 ， 68 \%$ 硫安飽和より得られた蛋白を 画分 6 とした.これら画分を加えた際の sedimentation rate の交進についてみると, 画分 4 と画分 5 が最も低濃 度で sedimentation rate を充進させることが認められ た. また zeta-potential についてみると, 画分 4 が最も 低濃度で電位の低下を示した。

2) DEAE-Cellulose column による分画

上記の各画分のうち, 画分 4 が $\mathrm{CaCO}_{3}$ suspension に 最も強い凝集効果をもつことが判明したので，この画 分を DEAE-Cellulose Column で分画 した. 0.01M, $0.05 \mathrm{M}, 0.1 \mathrm{M}$ phosphate buffer $お_{0} よ ひ ゙ 0.1 \mathrm{M}$ phosphate buffen に0.1M Nacl 溶液を加えて 溶出した画分をそれ ぞれ $\mathrm{P}_{1}, \mathrm{P}_{2}, \mathrm{P}_{3}$ および $\mathrm{P}_{4}$ とした。 $\mathrm{P}_{1}$ および $\mathrm{P}_{2}$ は sedimentation rate の充進は殆んど無く, $\mathrm{P}_{3}$ が最も低濃 度で sedimentation rate の充進を起こし， $\mathrm{P}_{4}$ がこれに 次いだ。

zeta-potential についてみると, $\mathrm{P}_{3}$ が最も低い濃度で 電位の減少を起こし, 次いで $\mathrm{P}_{4}, \mathrm{P}_{2}$ の順になつた. $\mathrm{P}_{1}$ では zeta-potential の変化は起こらなかつた.

3） Cellulose acetate 膜に上る電気泳動.

$\mathrm{P}_{1}$ は $\gamma$ globulin 領域の蛋白のみであり, $\mathrm{P}_{2}$ は $\beta$ globulin 領域の蛋白が主成分であり， $\mathrm{P}_{4}$ は albumin が 主成分であつた。 $\mathrm{P}_{3}$ は albumin と $\alpha_{1}$ globulin 領域の 蛋白であつた。 また $\alpha_{1}$ globulin 領域の蛋白は PAS 染 色陽性であつた.

以上の成績より強い凝集作用をもつ成分は $\alpha_{1}$ globulin あるいは $\alpha_{1}$ globulin と albumin の共存したものによ ると考兄られる。これらの蛋白は尿中コロイドの凝集を 起こすことが考えられ，尿路結石の形成に重要な因子と なつているるのと思われる.

この稿を終わるに際し, 御指導, 御校閲を賜わった本 学第二医化学教室吉沢善作教授ならびに東北薬科大学癌 
研究所川内広明教授に深甚なる感謝の意を表する. 当教 室杉田篤生助教授に深謝する。 また, 実験に際して種々 御助言いただいた東北薬科大学癌研究所榊原房夫助手に 深謝する.ささに直接御指導いただいた当教室木村行雄 講師に感謝する。

\section{文献}

1) Kimura, Y. and Kisaki, N.: Urol. Int., 31, 355, 1976.

2) Addis, T.: Harvey Lectures, 23, 222, 192728.

3) Boyce, W.H., Gurvey, F.K. and Norflect, C.M.: J. Clin. Invest., 33, 1287, 1954.

4) Gunton, R. and Burton, A.C.: J. Clin. Invest., 26, 892, 1947.

5) Goddard, P.F. and Hobbs, J.R.: Proc. Roy. Soc. Med., 61, 335, 1968.
6) Grant, G.H.: J. Clin. Path., 10, 360, 1957.

7) Möerner, K.A.H.: Skandinav. Arch. F. Physiol., 6, 332, 1895.

8) Tidstr $\phi$ m, B.: Scand. J. Clin. and Lab. Invest., 15, 259, 1963.

9) Berggård, I.: Clinica Chimica Acta, 6, 413, 1961.

10) Rigas, D.A. and Heller, C.G.: J. Clin. Invest., 30, 853, 1951.

11) Rowe, D.S. and Soothill, J.F.: Clin. Sci., 21, 75, 1961.

12) Tidstr $\phi$ m, B.: Acta. Med. Scand., 174, 385, 1963.

13) Boyce, W.H.: Renal Stone Research Symposium, p. 181, J. and A. Churchill Ltd. London, 1969.

（1977年 2 月 28 日受付，特別掲載） 